\title{
Mobile Based for Basic English Learning Assessment with Augmented Reality
}

\author{
Zuhri Syarifudin*, Suharjito \\ Computer Science Department, BINUS Graduate Program - Master of Computer Science, Bina Nusantara University, Jakarta, \\ Indonesia 11480
}

\begin{tabular}{l} 
A R T I C L E I N F O \\
\hline Article history: \\
Received: 21 February, 2020 \\
Accepted: 31 March, 2020 \\
Online: 24 April, 2020
\end{tabular}

Keywords:

Augmented Reality

Mobile Application

Formative Assessment

Basic English Learning

\begin{abstract}
A B S T R A C T
Nowadays Augmented Reality (AR) is very popular in teaching and learning, especially in leading student to observe learning material targets which supported by online learning resources using mobile device and wireless technology. Because English is a foreign language, most students have problems in learning English. Generally, their problems were related to low motivation, bad study habit and attitude toward learning. Significantly, formative assessment is important in improving student learning achievement. furthermore, a formative assessment can help teachers to identified students' progress, modify instruction, provide immediately feedback and achieve learning goals. The aim of this study was to build Mobile Based Assessment with Augmented Reality based on formative assessment mechanism, examine student's learning achievement, student's acceptance and student's motivation in Basic English Learning. A total of 34 elementary students of Grade 4 were selected to participated in this study. The descriptive analysis was used to analyze and described the data obtained. The result indicated that using Mobile Based Assessment with Augmented Reality based on formative assessment mechanism improved not only student's learning achievement but also student's motivation in Basic English Learning.
\end{abstract}

\section{Introduction}

Technology has greatly influenced our daily lives. Starting from the way we live, work, think, communicate, and interact with others continuously incessantly in all aspects of our lives [1]. In education section, information technology is one of the educational revolutions that has developed an education system to be more effective and efficient. According to [2] Mobile Based Assessment (MBA) is an alternative assessment model while complementing the Paper Based Test (PBT) or Computer Based Test (CBT) evaluation system. MBA has many advantages over PBA or CBT, such as ease of administration, saving time, not depending on location, adaptability, personalization and social interaction [3].

Augmented Reality (AR) is a technology which can translates or displays virtual data [4] and combine virtual objects into the real world [5]. AR can also be applied and connected with various technologies such as wearable computers, mobile devices and immersion technologies [6]. In education section, AR provides a great opportunity in online learning, especially in practical subjects [7]. AR technology can be applied in language learning too. Written, Vocabulary and oral comprehensive were important input

${ }^{*}$ Corresponding Author Zuhri Syarifudin, Bina Nusantara-Jakarta, 534-5830,

Indonesia, syarifudin.zuhri@binus.ac.id

www.astesj.com

https://dx.doi.org/10.25046/aj050297 for students in language learning can be presented more interactive and more interesting. It can made student feeling interesting and spending more time to learn language learning [8]. Through ARBased Mobile Learning material, also can help students to understand the lesson because students are directly involved in learning activities [9].

Using foreign languages in written communication is very difficult, because using foreign languages in written communication requires knowledge of linguistic and knowledge of meaning. English as Foreign Language (EFL) tends to make it difficult for students who have limited linguistic knowledge and background in understanding meaning [10]. English is a foreign language, most students spending more time for studying English composition and several students lost their motivation and their confidence in the learning process. This is caused when students practice in the writing skills, the students usually facing some problems (for example, inadequate vocabulary, less experience on the subject of composition and tough to describing their ideas) [11].

Several studies have investigated the formative assessment was significantly very important in improving student achievement, help teachers to understand student's progress 
during the learning process, modify learning methods and provide direct feedback $[12,13,14,15]$. Direct feedback given to students is very important. Based on the researchers' statement on feedback, it can be concluded that during the feedback learning process it is very contributing, therefore feedback is part of formative assessment [16].

To enhance student's performance in the Basic English Learning, this study proposed a Mobile Based Assessment with Augmented Reality based on formative assessment mechanism, to examine student's learning achievement, student's motivation and student's acceptance in Basic English Learning. The following research questions are examined in this study:

- how to build Mobile-Based Assessment with Augmented Reality to measurement student's achievement

- do the students who study with Mobile-Based Assessment with Augmented Reality have better motivation learning

- how student's acceptance who studied with MobileBased Assessment with Augmented Reality.

\section{Related Work}

Research on the use of Augmented Reality on 100 students grade 7 junior high school in learning "Solar System and Beyond" conducted by [17] has a positive impact on student's achievement and student's attitudes compared to traditional learning methods and textbooks. Based on the results of the study, several reasons for student's achievement and student's attitude who using AR are better than traditional learning methods in the learning process : (1) AR technology increases students' sense of interest and motivation in learning; (2) Objects transformation in AR draw student's attention; (3) 3D objects in AR enable students to observe learning material in more detail compared to $2 \mathrm{D}$ objects; (4) AR technology makes the learning process more interesting; (5) Students feel AR technology is a new and interesting technology, even some students think AR is like magic; (6) 3D objects in AR, attract the attention of students, allow students to be able to observe more thoroughly and make students feel the learning process of learning by doing; (7) AR technology makes learning in the classroom more enjoyable, attracting students' attention and interest in learning material.

The study has been done by [18] comparing academic achievement and student's motivation with 93 students at private school and public school in Mexico on Geometry learning using ARGeo and WebGeo as learning media. The results of the study revealed : (1) Based on the results of the Pre Test and Post Test that have been conducted on public school and private school, students who learn to use ARGeo have better academic achievements than students who learn to use WebGeo; (2) Students at Public School, learning Geometry using ARGeo are more effective than WebGeo, while students at Private School, learning Geometry using ARGeo and WebGeo are equally effective; (3) Students at Public School and Private School who learn to use ARGeo have good learning motivation compared to students who study with WebGeo.

The study conducted by [9] combines AR and Global Positioning technology in the learning process of English as a
Foreign Language (EFL), especially in writing. Students are asked to go around the campus area while activating the camera to aim at the learning target, then the system will display learning material information in English composition on the smartphone screen accordance with the target captured by the camera for observation. After making observation, students are asked to make an essay to test their writing skills using English. The results of this study reveal AR-Based Learning is very helpful for students in observing learning material, adding information and vocabulary, adding linguistic knowledge and meaning knowledge so that students can produce meaningful and good essays.

Using AR technology in interactive English language learning through the Phonics approached to Consonant-VocalConsonant material in kindergarten provides fun, interactive and effective learning. Through this method, students are enthusiastic and pro-active during the learning process and increase students' reading interest [19].

The study conducted by [20] presents an AR Book System based learning system to introduce Hakka Culture in Taiwan. The students read the book using the AR application using a mobile device and then the system will display virtual information in the form of 3D objects, audio and video narration. Researchers conducted experiments with 153 students and explained that learning using the AR Book system increases motivation, interest and attitude especially in reading context in the learning process.

Research by [21] compares learning strategy on u-learning using Augmented Reality based on formative assessment with conventional Augmented Reality. A total of 39 students majoring in architecture were divided into experimental groups of 19 students using Augmented Reality based on formative assessment and control groups of 20 students using conventional Augmented Reality. The learning scenario carried out by the two groups is observing the buildings in the Museum of World Religions to measure student's achievement, motivation learning and cognitive load (mental load and mental effort). The results of the study revealed: (1) Student's achievement in the experimental group was greater than in the control group. This is because formative assessment allows students to develop a sense of responsibility towards learning so that they actively build student understanding; (2) There is no significant difference Mental load between the two groups, because both groups studied the same content of learning material. But mental effort in the experimental group is greater than the control group, this reveals Augmented Reality (AR) based on formative assessment is a good learning strategy approach for students; (3) Motivation learning in the experimental group is greater than in the control group because feedback in formative assessment can be used by students to revise their learning activities to complete their assignments efficiently.

Previous research study demonstrated how AR technology can support the learning process and make effective learning. Therefore, in this study the researchers intend to make a Mobile Based Assessment with Augmented Reality in Basic English Language Learning based on formative assessment mechanism to examine student's learning achievement, student's motivation and student acceptance in Basic English Learning. Through this application, it is expected to be able provide information to the 
teacher about what students have learned, show what difficulties students might find in the learning process, and help the teacher adjust the teaching to maximize the learning.

\section{Research Methodology}

Based on research conducted by [21], this study used a formative assessment strategy method based on the AR-based learning system in designing mobile applications for the assessment of basic English language learning using AR. During the learning process, the students will be learning the course using formative assessment mechanism. Through this mechanism, students will be guided to observe each learning material and then answer a series of questions that arise based on the guidelines displayed by the learning system. As shown in Figure 1, there are three main phases in this study as explained in more detail below.

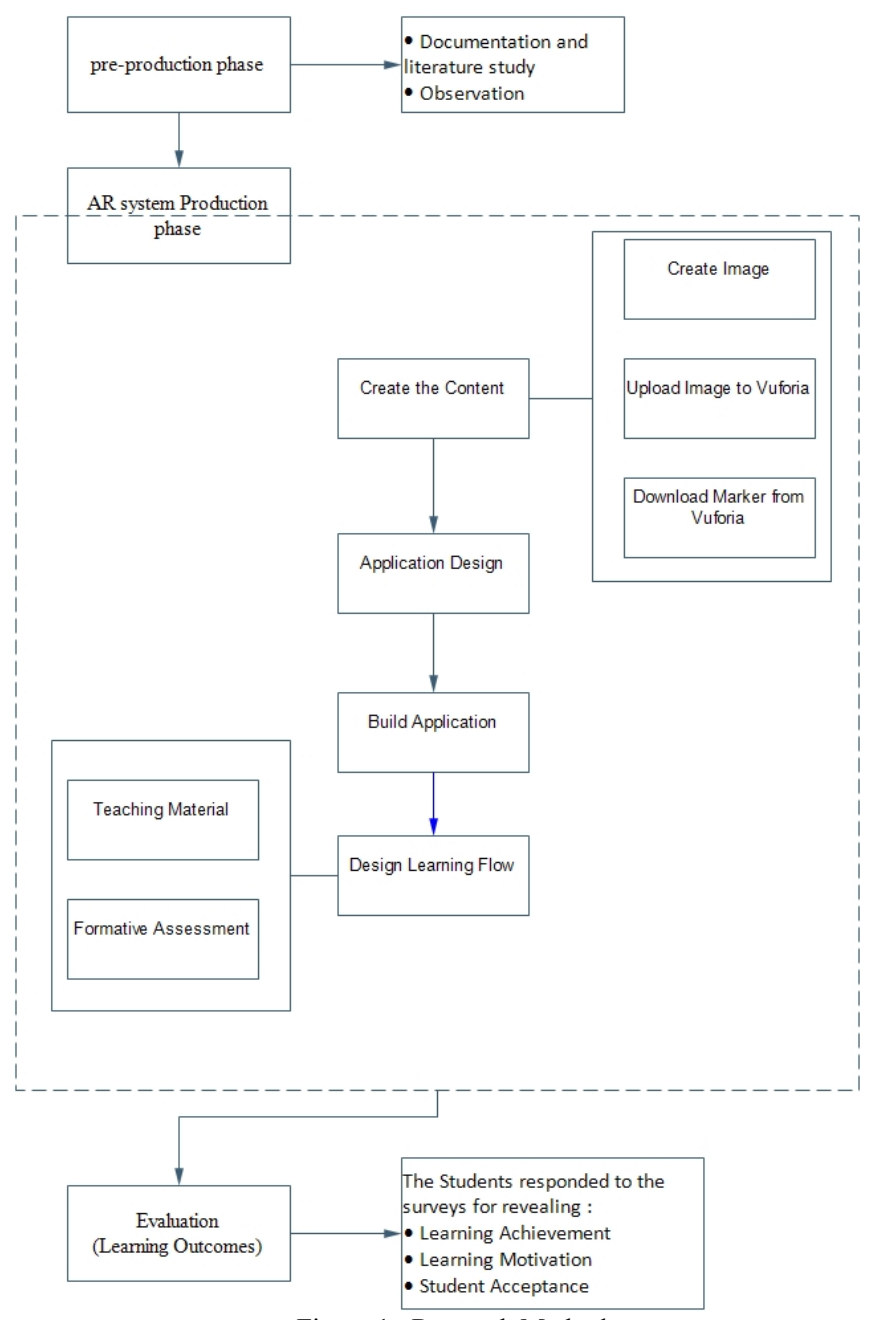

Figure 1: Research Method

The pre-production phase: the stages of documentation and literature study related to research problems and preliminary surveys (observation) to obtain the data needed. In the literature study phase, researchers collect a number of books, archives, articles, journals and relevant documents about the use of AR technology in the learning process and learn how to implement AR in the learning process. While at the observation stage, researchers conduct observations or reviews carefully and directly at the research site to determine the conditions that occur.
AR system Production phase: the stage of making a mobile application for the assessment of basic English language learning using AR. Preparation started from finding information about learning material, determining 3D objects, designing book markers and integrating into the Vuforia library and making Augmented Reality in Unity until the application is ready for use by users as shown on Figure 2 .

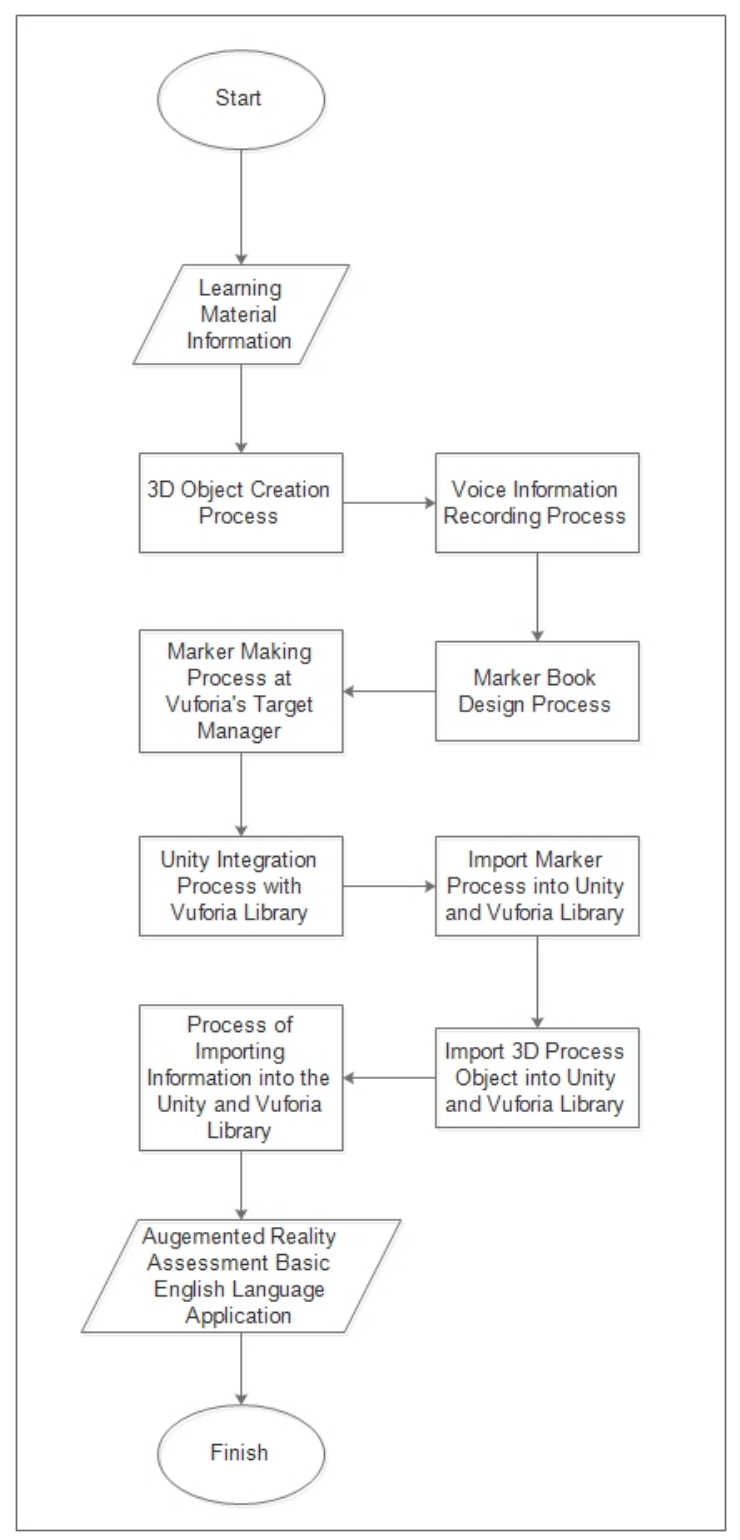

Figure 2: AR Application Design Flowchart

Hardware specifications that researchers use for making AR applications can be seen in Table 1 and software specifications used in Table 2.

\begin{tabular}{|c|l|l|}
\multicolumn{3}{|c|}{ Table 1 Hardware Specification } \\
\hline No & \multicolumn{1}{|c|}{ Component } & \multicolumn{1}{c|}{ Specification } \\
\hline 1 & RAM & $4 \mathrm{~GB}$ \\
\hline 2 & SSD & $512 \mathrm{~GB}$ \\
\hline 3 & VGA & $1024 \mathrm{MB}$ \\
\hline 4 & Processor & Intel Core i3 \\
\hline 5 & Camera & Logitech 2 MP \\
\hline
\end{tabular}


Table 2 Software Specification

\begin{tabular}{|c|l|l|}
\hline No & \multicolumn{1}{|c|}{ Component } & \multicolumn{1}{c|}{ Specification } \\
\hline 1 & OS & Win10 \\
\hline 2 & IDE & Visual Studio Code 1.38.1 \\
\hline 3 & Framework & Unity 3D Version 2018.3.11.f1 (64bit) \\
\hline 4 & AR Library & Vuforia 8.1.10 \\
\hline 5 & Android Emulator & Bluestack \\
\hline
\end{tabular}

While the minimum device target for user requirement can be seen in Table 3.

Table 3 Minimum Device Target

\begin{tabular}{|c|l|l|}
\hline No & \multicolumn{1}{|c|}{ Component } & \multicolumn{1}{c|}{ Specification } \\
\hline 1 & Device & Android OS Based \\
\hline 2 & Android OS Version & 4.1 \\
\hline 3 & RAM & $1 \mathrm{~GB}$ \\
\hline 4 & API & 14 \\
\hline 5 & Camera & $8 \mathrm{MP}$ \\
\hline
\end{tabular}

This AR application was built for Android-based devices, researchers chose the Vuforia Framework as a library for making AR on Android. This application was developed with Visual Studio Code as an IDE for making AR applications and using Unity 3D Version 2018.3.11.f1 (64bit).

The AR application will display the views obtained from the camera on an android device. Then the camera will detect the presence of the marker where the marker is in the form of an ARBOOK book. When a marker is detected it will display virtual information in the form of $3 \mathrm{D}$ objects with audio narration and formative assessment.

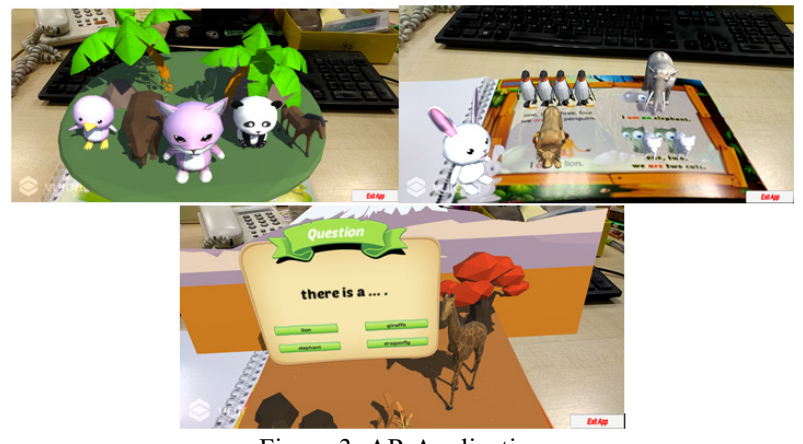

Figure 3: AR Application

The evaluation (learning outcomes) structure used in this study are learning achievement, learning motivation and student's acceptance. The subjects were 34 students who studied in 4th grade at an elementary school.

Pre-Test and Post-Test ware developed to evaluate students learning achievement. Pre-test aimed to evaluate the student's prior knowledge about the course content. Post-test aimed to evaluate student knowledge after using the system. Pre-Test and Post-Test both contained 10 multiple choice questions, with a perfect score is 100 .
Motivation Strategies for Learning Question (MSLQ) developed by [22] was adopted to developed motivation questionnaire. The motivation questionnaire consisted of 5 items in a five-point Likert scale.

\begin{tabular}{|c|c|c|c|}
\hline Pre-Test & Preparation & Implementation & Evaluation \\
\hline $\begin{array}{l}\text { evaluate the } \\
\text { student's prior } \\
\text { knowledge }\end{array}$ & $\begin{array}{l}\text { The researcher } \\
\text { introduced the } \\
\text { usege of AR } \\
\text { Book and AR } \\
\text { Application }\end{array}$ & $\begin{array}{l}\text { Students leam } \\
\text { the course } \\
\text { using AR Book } \\
\text { and AR } \\
\text { Application }\end{array}$ & $\begin{array}{l}\text { Students } \\
\text { responded to the } \\
\text { surveys: } \\
\text { 1. Achievement } \\
\text { Leaming (Post- } \\
\text { Test } \\
\text { 2. Motivation } \\
\text { Learning } \\
\text { 3. Student's } \\
\text { Acceptance }\end{array}$ \\
\hline
\end{tabular}

Figure 4: Evaluation Process

The student's acceptance questionnaire were developed with attitude questionnaire based on previous research [23] and [24] that has seven factors : perception of usefulness, perceived ease of use, teaching material, Interface Design, Multimedia Feature, Interactive Function, and Practicability. The student's acceptance questionnaire consisted of 20 items in a five-point Likert scale.

The overall Cronbach's alpha for the pre-post-test, motivation questionnaire, usefulness, perceived ease of use, teaching material, Interface Design, Multimedia Feature, Interactive Function, and Practicability were $0.753,0.929,0.774,0.832,0.881,0.739,0.703$, 0.861 and 0.914 respectively, which are acceptable.

\section{Finding and Result}

In this study, a material was designed supported with AR technology with an animation, 3D model object, and audio narration in order to help students better memorize the material. Assessment and immediately feedback helping student's for selfreflection in learning process. The implementation of learning basic English with Mobile Based Assessment with Augmented Reality in the classroom was presented in Figure 5.

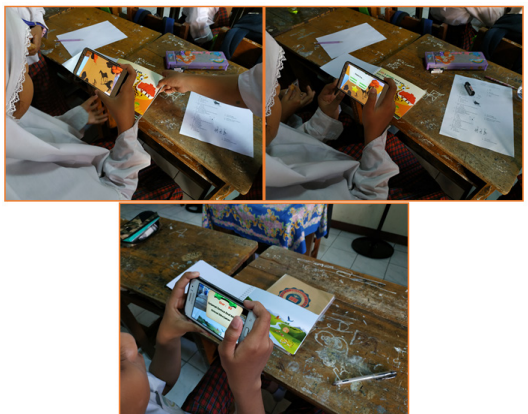

Figure 5: The Implementation of AR in the classroom

A SPSS was used to perform a statistical data analysis based on the result of the pre-test, post-test, learning motivation and student acceptance. Descriptive analysis was adopted to analyze and describe the result of each test and the questionnaires of the participant in basic English classroom towards course materials designed with augmented reality technology.

Pre-test was conducted to evaluate the student's prior knowledge about the course content before experimental learning activity. After participating in the experimental learning activity, the student took the post-test. Results of the pre- post-test are shown in Table 4. 
Table 4 Descriptive Analysis Results of pre- post-test

\begin{tabular}{lccc}
\hline & N & Mean & Std. Deviation \\
\hline Pre_Test & 34 & 63.24 & 14.189 \\
Post_Test & 34 & 68.53 & 19.288 \\
Valid N (listwise) & 34 & & \\
\hline
\end{tabular}

Based on Table 1 was shown a brief summary of the descriptive analysis results. For the Pre-Test obtained the Mean value was 63.24. As for the Post-Test value, the Mean value was 68.53. Seeing the results of the calculation from mean value as shown in the table, there is an increase in learning outcomes (achievement learning) after learning to use the AR application as seen in Figure 6 Pre-Test and Post-Test Diagram.

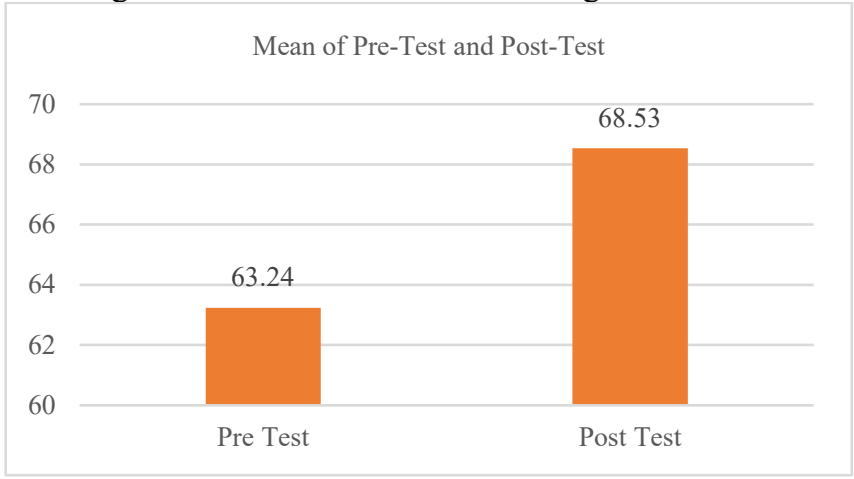

Figure 6: Pre-Test and Post-Test Diagram

The results of motivation learning related to this survey can be seen in Table 5 .

Table 5 Descriptive Analysis Results Motivation Learning

\begin{tabular}{|c|c|c|c|c|c|c|}
\hline \multirow{2}{*}{ Motivation } & STS & TS & $\mathrm{R}$ & $\mathrm{S}$ & SS & \multirow{2}{*}{ Mean } \\
\hline & 1 & 2 & 3 & 4 & 5 & \\
\hline \multirow{2}{*}{ Motiv1 } & 2 & 0 & 1 & 10 & 21 & \multirow{2}{*}{4.41} \\
\hline & $5,88 \%$ & $0,00 \%$ & $2,94 \%$ & $29,41 \%$ & $61,76 \%$ & \\
\hline \multirow{2}{*}{ Motiv2 } & 1 & 3 & 3 & 14 & 13 & \multirow{2}{*}{4.03} \\
\hline & $2,94 \%$ & $8,82 \%$ & $8,82 \%$ & $41,18 \%$ & $38,24 \%$ & \\
\hline \multirow{2}{*}{ Motiv3 } & 2 & 0 & 2 & 10 & 20 & \multirow{2}{*}{4.35} \\
\hline & $5,88 \%$ & $0,00 \%$ & $5,88 \%$ & $29,41 \%$ & $58,82 \%$ & \\
\hline \multirow{2}{*}{ Motiv4 } & 2 & 1 & 1 & 10 & 20 & \multirow{2}{*}{4.32} \\
\hline & $5,88 \%$ & $2,94 \%$ & $2,94 \%$ & $29,41 \%$ & $58,82 \%$ & \\
\hline \multirow{2}{*}{ Motiv5 } & 2 & 0 & 2 & 10 & 20 & \multirow{2}{*}{4.35} \\
\hline & $5,88 \%$ & $0,00 \%$ & $5,88 \%$ & $29,41 \%$ & $58,82 \%$ & \\
\hline \multicolumn{6}{|c|}{ Sum of Mean } & 4.29 \\
\hline
\end{tabular}

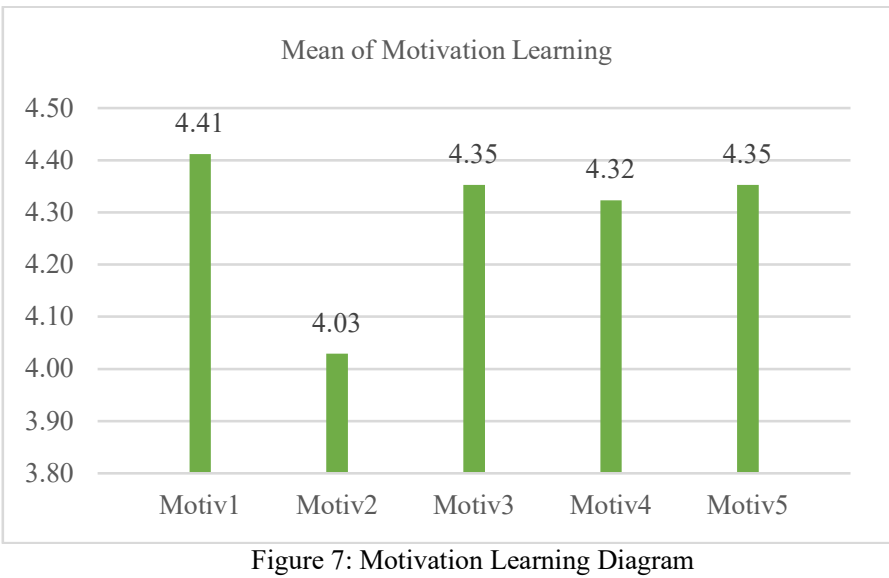

Based on Table 2 the students' answers to the questions asked for the Motivational Learning variable have an average of 4.03 to 4.35 with an average total value of 4.29 . This shows that most www.astesj.com students agree with the questions in the questionnaire which means students assessed that learning Basic English with Mobile Based Assessment with Augmented Reality have good motivation learning.

Usefulness, perceived ease of use, teaching material, Interface Design, Multimedia Feature, Interactive Function, and Practicability are used to measure student acceptance in English learning activities using the AR application. Student acceptance results related to this variable in each category can be seen in Figure 8 .
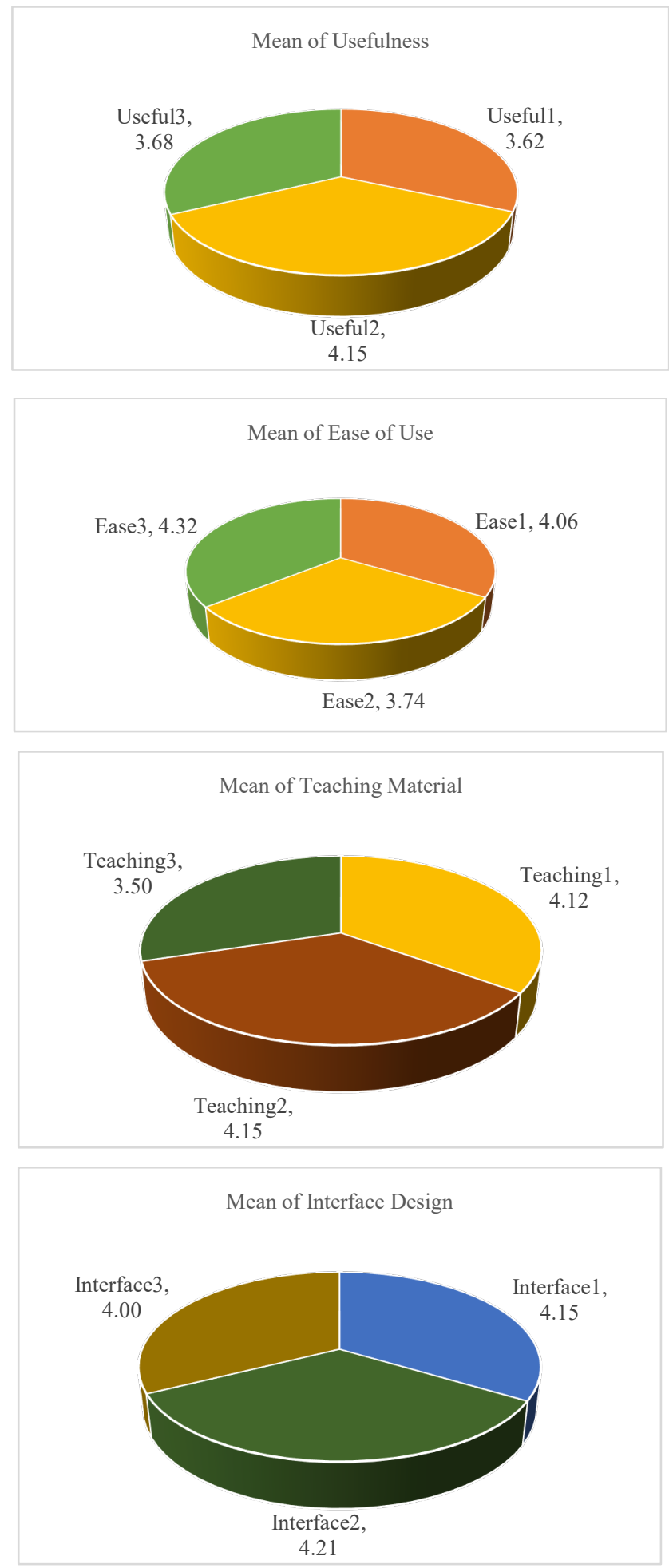


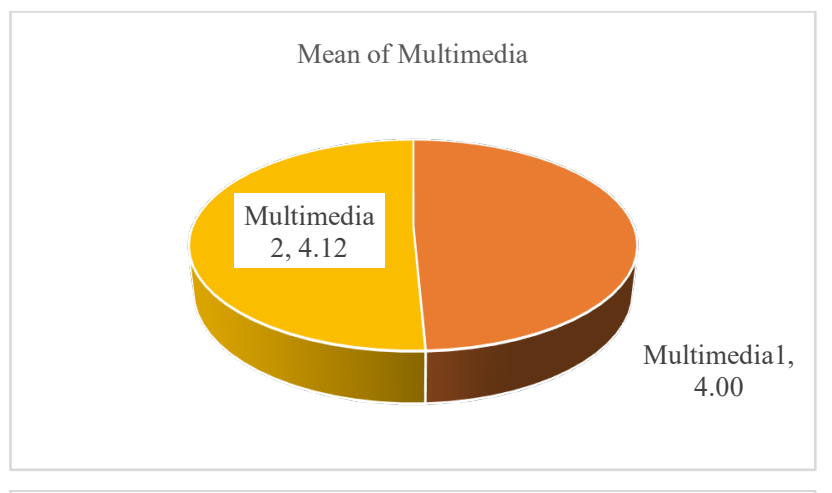

Mean of Interactive Function

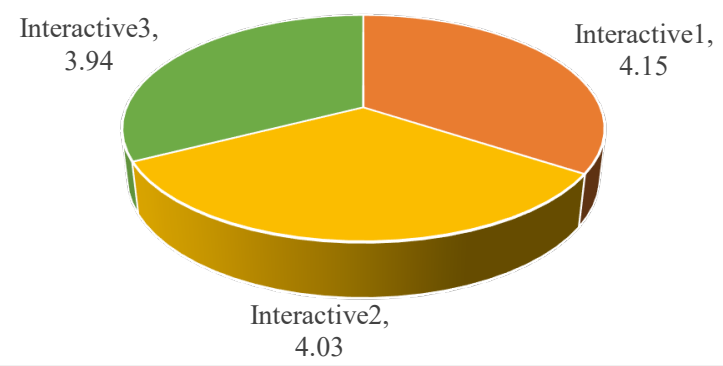

Mean of Practicability

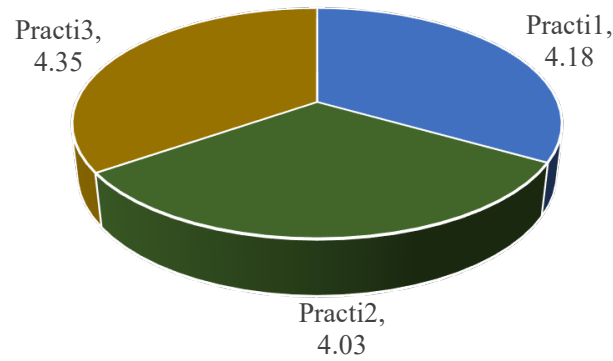

Figure 8: Descriptive Analysis Student's Acceptance Diagram

Information from Figure 8 is as follows:

a. Based on the usefulness can be seen from the Figure 8 has mean value of $3.62,4.15$ and 3.68 which shows that students feel quite satisfied with the benefits felt from the AR application.

b. $\quad$ Based on ease of use, has mean value of $4.06,3.74,4.32$ which shows that students can easily use the AR application.

c. Based on teaching material (teaching material) can be seen from the Figure 8 has mean value of 4.12, 4.15 and 5.50 which shows that students feel quite satisfied with the material displayed on the AR application.

d. Based on the interface design (interface design) seen in the Figure 8 has mean value of 4.15, 4.21 and 4.00 which shows that students feel the design of the application is good.

e. Based on multimedia features as shown in the Figure 8 has mean value of 4.06 and 4.12 which shows that students feel the 3D model and the information displayed is good.

f. Based on the interactive function in the Figure 8, it looks like it has mean value of $4.15,4.05$ and 3.94 which shows students feel the touch and assessment features are good enough.

g. Based on practicability as seen in the Figure 8 has mean value of $4.18,4.03$ and 4.35 which shows students feel this application is quite useful

Based on Figure 8, most students choose the option above doubt (3) namely the choice of agree (4) or strongly agree (5). this shows that students have good student's acceptance in the process of learning basic English using the AR application as seen in Figure 9 Student Acceptance Diagram.

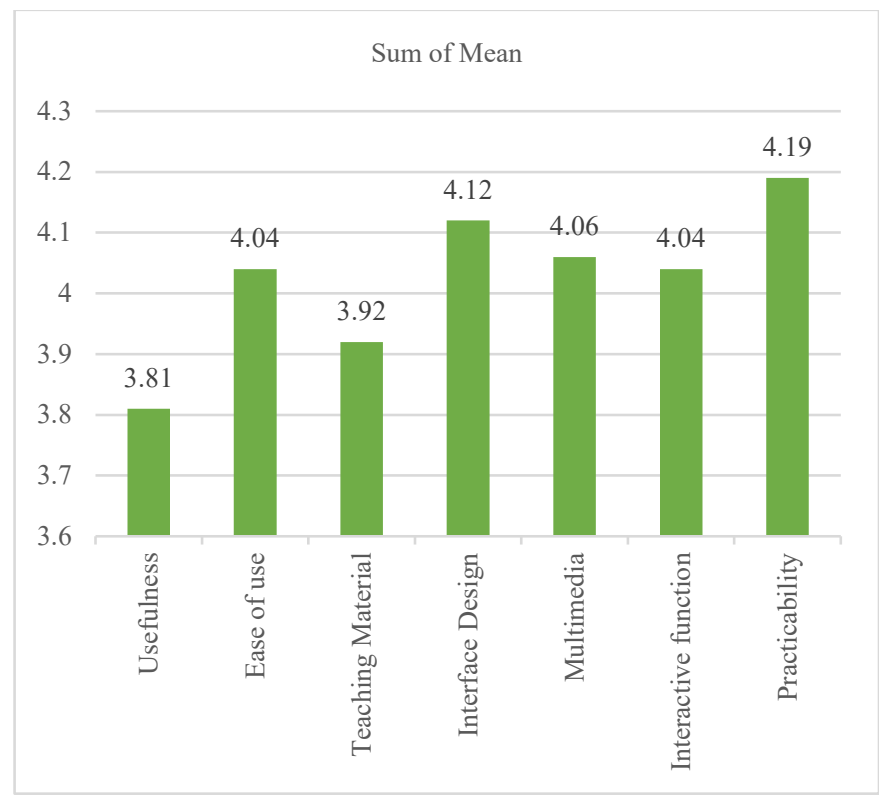

Figure 9: Student's Acceptance Diagram

Student's acceptance survey results that look like the picture 9. Student's Acceptance Diagram have similar result with research by [17] which revealing using AR technology in the learning process has a positive impact on student's acceptance. This is due to several reasons such as making students directly involved in learning so that learning is more fun, attracting students 'attention and students' interest in learning. The features contained in AR technology allow students to observe learning objects in more detail so allowed students to feel the experience of learning by doing.

\section{Conclusions}

All Based on the results of the calculation of survey data and the results of the evaluation of AR applications can be seen a positive response from students. Applications designed in this study have the advantage of being able to display information in the form of 3D models, animation, text, sound, assessment and feedback so provided different nuances in presenting information on learning material that is more interesting and interactive to students. In addition, students are interested in the further development of this application and the desire to further using this application as a complement of the learning tools (media learning). 


\section{Z. Syarifudin et al. / Advances in Science, Technology and Engineering Systems Journal Vol. 5, No. 2, 774-780 (2020)}

Based on the results obtained through this study, it can be concluded that the application of basic English learning using AR can help students in learning material and motivated students to learn English. There are some improvements and investigations that must be considered for future research, such as expanding the content of learning materials to meet the competency standards of learners, adding features of interaction between teacher and student or fellow students to support collaborative learning methods, conducting an statistical analysis involving teachers and students in learning process, and investigating student learning behavior to extend the explanation in this research.

\section{References}

[1] J. Challoner, 1001 Inventions that changed the world, Barron's, 2009.

[2] L. Johnson, S. A. Becker, M. Cummins, V. Estrada, A. Freeman and C. Hall, NMC horizon report: 2016 higher education edition, The New Media Consortium, 2016.

[3] S. A. Nikou and A. A. Economides, "A model for Mobile-based Assessment adoption based on Self-Determination Theory of Motivation," in Interactive Mobile Communication Technologies and Learning (IMCL), 2014 International Conference on, IEEE, 2014, pp. 86-90.

[4] M. Akçayır and G. Akçayır, "Advantages and challenges associated with augmented reality for education: A systematic review of the literature," Educational Research Review, vol. 20, pp. 1-11, 2017.

[5] T. C. Huang, M. Y. Chen and W. P. Hsu, "Do Learning Styles Matter? Motivating Learners in an Augmented Geopark," Journal of Educational Technology \& Society, vol. 22, pp. 70-81, 2019.

[6] X. Wei, D. Weng, Y. Liu and Y. Wang, "Teaching based on augmented reality for a technical creative design course," Computers \& Education, vol. 81, pp. 221-234, 2015.

[7] J. M. Andujar, A. Mejías and M. A. Márquez, "Augmented reality for the improvement of remote laboratories: an augmented remote laboratory," IEEE transactions on education, vol. 54(3), pp. 492-500, 2010.

[8] E. Solak and R. Cakir, "Exploring the Effect of Materials Designed with Augmented Reality on Language Learners' Vocabulary Learning.," Journal of Educators Online, vol. 12(2), pp. 50-72, 2015.

[9] P. H. E. Liu and M. K. Tsai, "Using augmented-reality-based mobile learning material in EFL English composition: An exploratory case study," British Journal of Educational Technology, vol. 44(1), pp. E1-E4, 2013.

[10] M. Saville-Troike and K. Barto, Introducing second language acquisition, Cambridge University Press, 2016.

[11] C. L. Shih, "The Relationship among Writing Self-efficacy, Apprehension, Motivation, Experience, and English Writing Performance of the Undergraduates and Graduate Students in Taiwan," Taiwan: National Kaohsiung Normal University, 2006.

[12] B. Bell and B. Cowie, "The characteristics of formative assessment in science education," Science education, vol. 85(5), pp. 536-553, 2001

[13] P. Black and D. Wiliam, Inside the black box: Raising standards through classroom assessment, Granada Learning, 2005.

[14] J. W. Gikandi, D. Morrow and N. E. Davis, "Online formative assessment in higher education: A review of the literature," Computers \& education, vol. 57(4), pp. 2333-2351, 2011.

[15] P. Perrenoud, "From formative evaluation to a controlled regulation of learning processes. Towards a wider conceptual field," Assessment in Education: Principles, Policy \& Practice, vol. 5(1), pp. 85-102, 1998.

[16] D. D. McMahon, D. F. Cihak, R. E. Wright and S. M. Bell, "Augmented reality for teaching science vocabulary to postsecondary education students with intellectual disabilities and autism," Journal of Research on Technology in Education, vol. 48(1), pp. 38-56, 2016.
[17] D. Sahin and R. M. Yilmaz, "The effect of Augmented Reality Technology on middle school students' achievements and attitudes towards science education," Computers \& Education, vol. 144, p. 103710, 2020.

[18] M. B. Ibáñez, A. U. Portillo, R. Z. Cabada and M. L. Barrón, "Impact of augmented reality technology on academic achievement and motivation of students from public and private Mexican schools. A case study in a middleschool geometry course," Computers \& Education, vol. 145, p. 103734, 2020.

[19] J. Sidi, L. F. Yee and W. Y. Chai, "Interactive English Phonics Learning for Kindergarten Consonant-Vowel-Consonant (CVC) Word Using Augmented Reality," Journal of Telecommunication, Electronic and Computer Engineering (JTEC), Vols. 9(3-11), pp. 85-91, 2017.

[20] K.-H. Cheng, "Reading an augmented reality book: An exploration of learners' cognitive load, motivation, and attitudes," Australasian Journal of Educational Technology, vol. 33, no. 4, 2017.

[21] H. C. Chu, J. M. Chen, G. J. Hwang and T. W. Chen, "Effects of formative assessment in an augmented reality approach to conducting ubiquitous learning activities for architecture courses," Universal Access in the Information Society, pp. 1-10, 2017.

[22] P. R. Pintrich and E. V. De Groot, "Motivational and self-regulated learning components of classroom academic performance.," Journal of educational psychology, vol. 82, no. 1, p. 33, 1990.

[23] M. H. Kurniawan, Suhartjio, Diana and G. Witjaksono, "Human Anatomy Learning Systems Using Augmented Reality on Mobile Application," Procedia Computer Science, vol. 135, pp. 80-88, 2018.

[24] C.-H. Chen, C.-Y. Huang and Y.-Y. Chou, "Effects of augmented realitybased multidimensional concept maps on students' learning achievement, motivation and acceptance," Universal Access in the Information Society, vol. 18, no. 2, pp. 257-268, 2017. 